DOI https://doi.org/10.30525/978-9934-26-182-4-7

\title{
LOW-GRADE INFLAMMATION IN PATIENTS WITH ASTHMA AND RISKS OF SARS-COV-2 INFECTION
}

\author{
Horishnyi I. M. \\ Student at the Medical Institute \\ Petro Mohyla Black Sea National University \\ Chernyshov O. V. \\ Candidate of Medical Sciences, Associate Professor, \\ Head of the Department of Pediatrics \\ Petro Mohyla Black Sea National University \\ Mykolaiv, Ukraine
}

Among all patients with allergic diseases, 300 million people suffers from bronchial asthma. The pathoimmune mechanisms of asthma has to be studied, particularly at the gene-molecular level [1].

A large epidemiological study - The World Health Organisation, conducted on behalf of the WHO in 70 countries (out of 192), showed that the prevalence of diagnosed asthma in adults is $4.3 \%$, ranging from $0.2 \%$ in China to $21 \%$ in Australia. Atopic pathology has acquired the status of a significant socioeconomic, medical problem for mankind. Complex mechanisms of anaphylaxis attract the attention of the scientific community $[2,3]$.

The literature describes the association between low-grade inflammation and obesity-associated bronchial asthma [4].

Low-grade chronic inflammation present in advanced age and chronic diseases-but not in bronchial asthma-produces a pro-inflammatory state that triggers a dysregulated immune response, favoring development of severe forms of COVID-19 and increasing lethality. In asthma, chronic eosinophilic inflammation protects against infection by producing a reduced interferonmediated response and a reduced number of ACE2 receptors [5].

The presence of low-grade inflammation correlates with the severity of respiratory disorders in bronchial asthma. According to a study by Vanessa Garcia-Larsen, Meinir Jones, James F. Potts, Roger B. Newson, Daniel Obaseki, Peter G.J. Burney a better FVC was associated with lower levels of CRP and IL-6. CRP, IL-6 and MPO were associated with a higher prevalence of lung obstruction.

In particular CRP and IL-6 were negatively associated with FVC (adjusted effect size per doubling (95\% Confidence Interval [CI] -0.05 (-0.08 to -0.03 ) 30 
and -0.09 (-0.14 to -0.04$)$, respectively) and CRP was positively related to a higher prevalence of FVC\&lt;LLN (OR per doubling 1.29 (95\% CI 1.04 to 1.61). CRP, IL-6 and MPO were positively associated with FEV1/FVC\&lt;LLN (Odds Ratios [OR] per doubling [95\% CI] 1.37 [1.11 to 1.70]; 1.73 [1.14 to 2.64]; and 1.22 [1.00 to 1.48], respectively [6].

The mechanisms of pathoimmunological processes in the course of COVID-19 infection in patients with asthma still need to be studied, but many sources indicate a positive effect of glucocorticoids on the protection of patients with asthma from COVID-19 virus. The role of low-grade inflammation is important in the infection of asthmatics with COVID-19 virus.

Data on the effect of basic asthma therapy on the risks of infection and severe COVID-19 were systematized by Ostrovsky M. ACE2 and TMPRSS2 is statistically significantly lower in patients who took ICS compared with the control group of subjects who do not use ICS [7]. The lower expression of ACE2 and TMPRSS2 with ICS use warrants prospective study of ICS use as a predictor of decreased susceptibility to SARS-CoV-2 infection and decreased COVID-19 morbidity [8]. Therefore, during a pandemic, compliance with basic asthma therapy, especially inhaled glucocorticoids, is important.

The basis of chronic pathoimmunological processes in asthma is low-grade inflammation, especially in asthma associated with obesity and atopic asthma. Further studies of low-grade inflammation in asthma are needed to determine the existence of molecular cellular mechanisms that can prevent SARS-CoV-2 infection.

\section{References:}

1. Горішний I. Бронхіальна астма як атопічне захворювання. Les tendances actuelles de la mondialisation de la science mondiale. 2020. URL: https://doi.org/10.36074/03.04.2020.v2.09

2. Horishnyi, I. M., Chernyshov, O. V. (2021). Leading atopic pathologies in children on the territory of Mykolaiv Region. Innovative Solution in Modern Science, 1(45), 90-97.

3. Фещенко Ю. І. Нові підходи покращення лікування бронхіальної астми у світовій практиці / Ю. І. Фещенко // Астма та алергія. 2019. - № 4. - C. 56-57.

4. Understanding the relationship between obesity and asthma. Research Features. 2021. No. 137. URL: https://doi.org/10.26904/rf-137-1660102578

5 Suárez-Reyes A., Villegas-Valverde C. A. Implications of lowgrade inflammation in SARS-COV-2 immunopathology. MEDICC Review. 2021. Vol. 23, no. 2. URL: https://doi.org/10.37757/mr2021.v23.n2.4 
6. Vanessa Garcia-Larsen, Meinir Jones, James F. Potts, Roger B. Newson, Daniel Obaseki, Peter G.J. Burney. Low grade systemic inflammation and lung function outcomes in European adults from the global asthma and allergy network of excellence (GA2LEN) follow-up survey. European Respiratory Journal, Sep 2014, (44).

7. Островський M. М. Бронхіальна астма в умовах пандемії COVID-19: SMART-стратегія для контролю астми та попередження загострень. Украӥнський пульмонологічний журнал. 2021, № 1.

8. COVID-19-related Genes in Sputum Cells in Asthma. Relationship to Demographic Features and Corticosteroids / M. C. Peters et al. American Journal of Respiratory and Critical Care Medicine. 2020. Vol. 202, no. 1. P. 83-90. URL: https://doi.org/10.1164/rccm.202003-0821oc

DOI https://doi.org/10.30525/978-9934-26-182-4-8

\title{
СТАН МІКРОБІОЦЕНОЗУ СТАТЕВИХ ШЛЯХІВ У ЖІНОК 3 ХРОНІЧНИМИ ЗАПАЛЬНИМИ ПРОЦЕСАМИ ВНУТРІШНІХ СТАТЕВИХ ОРГАНІВ НА ТЛІ ВАРИКОЗНОГО РОЗШИРЕННЯ ВЕН МАЛОГО ТАЗА
}

\author{
Дрогомирецька Н. В.
}

кандидат медичних наук,

асистент кафедри акушерства та гінекології імені І. Д. Ланового Івано-Франківський національний медичний університет м. Івано-Франківськ, Украӥна

Висока частота хронічного сальпінгоофориту, який превалює над іншими формами запальних захворювань органів малого таза, пояснюється несвоєчасним та неадекватним лікуванням гострих запальних захворювань. Особливістю хронічних запальних процесів внутрішніх статевих органів (ХЗПВСО) є затяжний, нерідко стертий перебіг, часті рецидиви, наявність численних ускладнень (безпліддя, порушення менструальної функції, ризик виникнення позаматкової вагітності, тазовий біль) і резистентність до терапії.

Варикозне розширення вен малого таза (ВРВМТ) зустрічається переважно у жінок репродуктивного віку. Дана патологія не лише супроводжує різні гінекологічні захворювання, але й може бути причиною хронічного тазового болю (ХТБ). Розширення вен малого таза до 